Alhan D Al-Moula

BDS, MSc (Lec.)

Fayhaa A Al-Mashhadane

BDS, MSc (Lec.)

Jawna'a K Mammdoh

BDS, MSc (Lec.)

\section{Effects of 6- Mercaptopurine on Salivary Glands in Rabbit}

\author{
Department of Dental Basic Sciences
}

College of Dentistry, University of Mosul

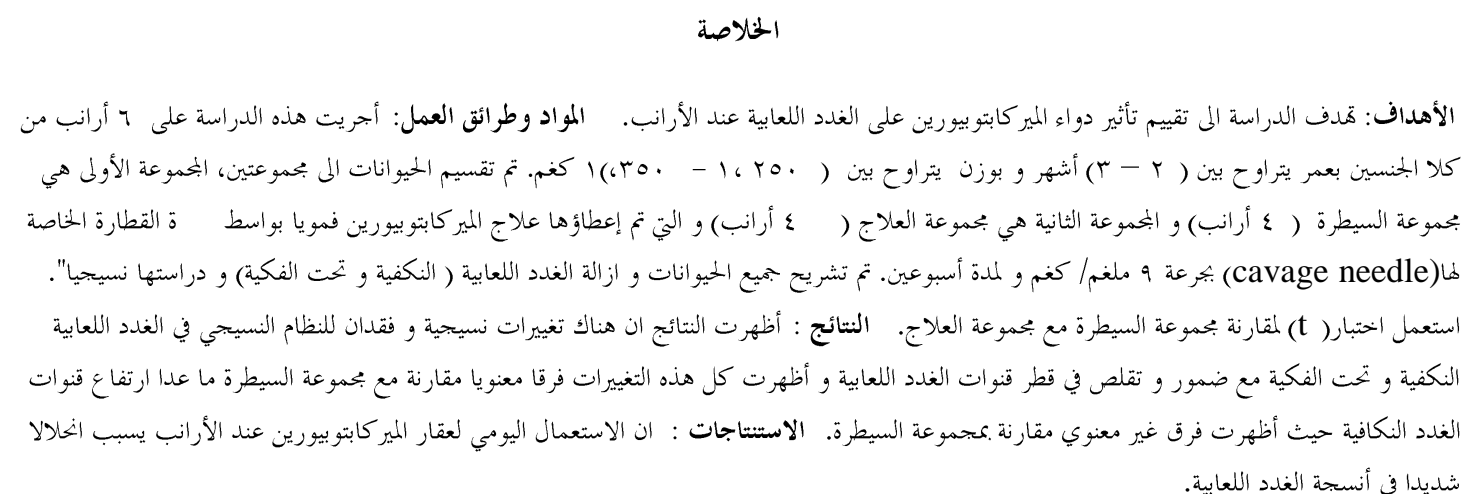

\title{
ABSTRACT
}

Aims: To study the effect of 6 - Mercaptopurine on salivary glands of rabbits. Materials and Methods: This study was carried out on 6 young rabbits of both sexes, aged $2-3$ months, and weighing 1.250-1.350 Kg. They were divided into control group (4 rabbits) which received no any treatment, and treatment group (4 rabbits) that were treated by $6-\mathrm{MP}$ in dose of $9 \mathrm{mg} / \mathrm{Kg}$ for duration of 2 weeks, the drug was administered orally by cavage needle. All animals were dissected and salivary glands (parotid and submandibular glands) were removed from right and left sides, then slides were made and morphometric analysis were made using filar micrometer, a photographs were done and $\mathrm{t}-$ test analysis was used to compare two groups. Results: There was loss of architecture of both parotid and submandibular salivary glands with disarrangement of acini. Acinar cells become smaller in diameter that was associated with increase in the interstitial spaces. There was atrophy and shrinkage of striated ducts and all these changes were significant compared to control group except that for parotid gland which showed no significant differences in height of intercalated duct cells compared to control group. Conclusions: Daily administrations of $6 \mathrm{MP}$ for rabbits produced severe degenerative changes in the salivary glands.

Key_Words: 6 - Mercaptopurine,chemotherapeutic agents, salivary glands, rabbits.

Al-Moula AD, Al-Mashhadane FA, Mammdoh JK. Effects of 6 - Mercaptopurine on Salivary Glands in Rabbit. Al-Rafidain Dent J. 2012; 12(2): 266-273.

Received: 2/3/2011 Sent to Referees: $8 / 3 / 2011$ Accepted for Publication: 18/4/2011

\section{INTRODUCTION}

Cancer chemotherapeutic agents are not selectively tumoricidal, they tend to produce more extensive injury to cancer cells, but they damage normal cells as well, causing permanent damage to normal tissues, the amount of this damage and its severity is usually based on the type ,amount and duration of drug used to treat the disease. ${ }^{(1)}$

Six- mercaptopurine (6MP), a key drug for the treatment of leukemia in children $^{(2)}$ is considered to be one of the most important and commonly used cytotoxic drug,it functions as analogs of a natural purines, hypoxanthine and guanine and metabolized into 6 - thioguanine which is the active compound and into methylated metabolites. ${ }^{(3-5)}$

Oral manifestations are especial prominent feature of the toxicity of this agent including dry mouth which is one of the side effects of anticancer drugs . They affect salivary glands and reducing flow of saliva causing xerostomia. ${ }^{(6)}$ 
Azathioprine, an imidazolyl derivative of 6MP have been reported to cause severe changes in glandular architecture and cellular morphology of parotid glands of rats ${ }^{(7-9)}$. Another study of $6 \mathrm{MP}$ has been found to have antithyroid properties in rats. $^{(10)}$

\section{MATERIALS AND METHODS}

In this study, 8 rabbits of both sexes were used, they were from local markets, aged 2-3 months weighing 1.250-1.350 $\mathrm{Kg}$ and kept in a standardized animal house condition with room temperature of $25 \pm 2{ }^{\circ} \mathrm{C}$. The animals were divided into 2 groups, the control group which include 4 rabbits that received no any treatment and the other group which include 4 rabbits treated by 6 - mercaptopurine (Orion Coporation, Turku, Finland) in dose of 9 $\mathrm{mg} / \mathrm{Kg}$ calculated according to body weight of animals for duration of 2 weeks $^{(11-14)}$, the drug was administered orally by cavage needle, then all animals were anesthetized with intramuscular injection of mixture of $0.5 \mathrm{mg} / \mathrm{Kg}$ xylazine hydrochloride (Holland, Castenray, Interchemra) and $50 \mathrm{mg} / \mathrm{Kg}$ ketamine hydrochloride (Aleppo - Syria, ElSaad) ,then sacrified.

Face and neck dissection was done for all animals, the salivary glands (parotid and submandibular glands) were removed from right and left sides. Each gland were divided into fine small pieces, fixed in alcoholic lavdosky fixative for $24 \mathrm{hrs}$, then dehydrated in ascending gradies of alcohol, using 50\% - 70\% - 90\% and 2 changes of absolute alcohol respectively with a period of one hour for each, then cleaned by 2 changes of xylene with a period of one hour for each, finally they were embedded in 3 changes of $60^{\circ} \mathrm{C}$ melting point paraffin was for $2 \mathrm{hrs}$ each. The blocks were cut with an average thickness of $4 \mu \mathrm{m}$ using rotary microtome, mounted on slides and stained with hematoxyline and eosin .Delafied Hematoxyline and Eosin for general morphological study. ${ }^{(15)}$ Morphometric analysis showed the diameter of acini, intercalated, straited ducts, and the height of cells of acini, intercalated and striated ducts were measured with a filar micrometer (ocular lens) mounted instead of the eye piece of a microscope. Diameter was measured from basement membrane to basement membrane of the cell. Height was measured from center to basement membrane of the cell, then a photograph was done for each slide and $\mathrm{t}$ - test analysis was used to compare between control and treatment groups.

\section{RESULTS \\ Physical and clinical \\ observations:- \\ Side effects like alopecia, dermatitis, gastrointestinal effects and activity of the animals was not observed.}

\section{Control group:-}

Figure 1: normal histological appearance of the parotid gland showing the general structure of the gland and connective tissue septa dividing the glandular tissue into lobules.

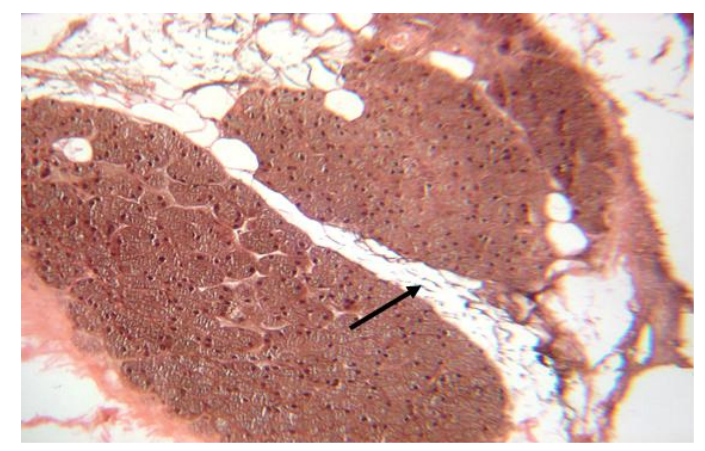

Figure (1): light micrograph of control parotid section, showing the general structure of the gland and connective tissue septa (arrow) .H\&E. [ X-165].

Figure (2) normal histological appearance of the parotid gland which is entirely serous secretory gland. The secretory endpieces are mostly acinus, the serous acini lined by pyramidal cells with eosinophilic cytoplasm, the nuclei are deeply basophilic and rounded in shape, situated in the basal third of the cells. The intercalated ducts seen in between the acini, they are smaller in diameter and lined by a single layer of law cuboidal epithelium, their boundaries are indistinct and have centrally placed rounded neuclei. The striated duct few in number with distinct boundaries and lined by a single layer of columnar epithelium. (Table 1) 


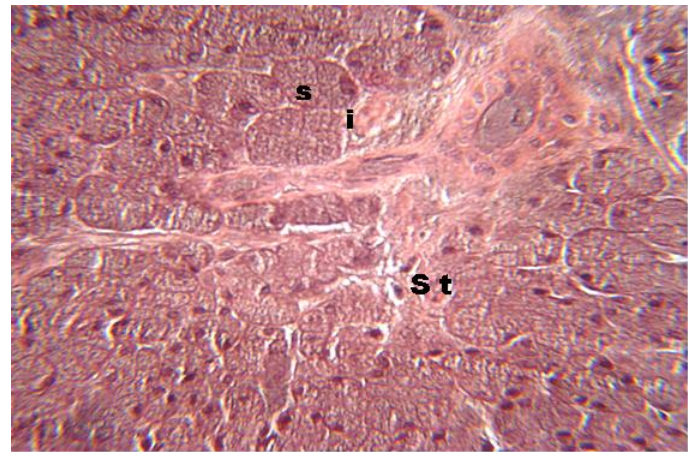

Figure (2): light micrograph of control parotid section, showing serous acini ( $\mathrm{s}$ ) and intercalated duct (i),striated duct ( st ) .H\&E. [ X- 370 ].

Table (1): Mean and standard deviation of the measurement of acini and intralobular ducts in parotid glands

\begin{tabular}{lccccc}
\hline & \multicolumn{2}{c}{ Control } & \multicolumn{2}{c}{ Treated } & P - value \\
Parameters & Mean $(\mu \mathrm{m})$ & SD & Mean $(\mu \mathrm{m})$ & SD & \\
Diameter of acini & 22.75 & 3.24 & 19.29 & 3.18 & 0.000 \\
Height of acinan cell & 10.67 & 2.05 & 8.58 & 1.68 & 0.000 \\
Diameter of intercalated ducts & 15.69 & 2.44 & 12.21 & 1.65 & 0.000 \\
Height of intercalated duct cells & 5.57 & 1.52 & 5.08 & 1.51 & 0.271 \\
Diameter of striated ducts & 33.33 & 12.60 & 19.29 & 5.58 & 0.000 \\
Height of the striated duct cells & 9.46 & 3.74 & 7.43 & 1.78 & 0.005 \\
\hline
\end{tabular}

* significant at $p \leq 0.005$

Figure. 3- Normal histological appearance general structure of the gland. of the submandibular gland showing the

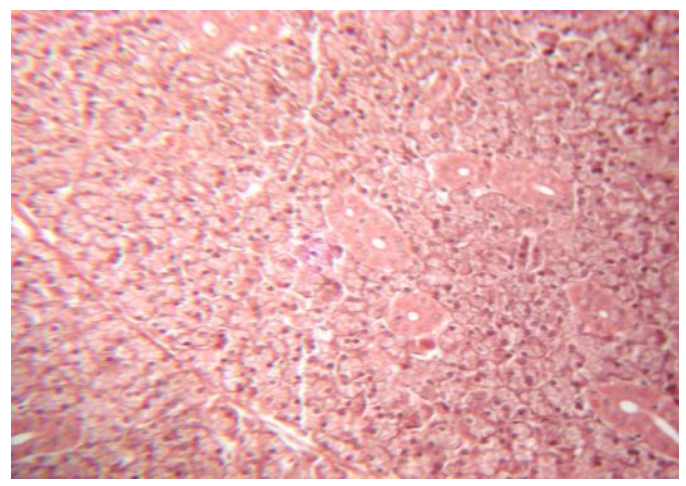

Figure (3): light micrograph of control submandibular section, showing the general structure of the gland. H\&E. [ X-165 ].

Figure (4) normal histological appearance of the submandibular gland which is seromucous acini larger in diameter than those of parotid gland and the boundaries of cells lining more distinct (clear), while the cytoplasm appears less intensity to stain with eosin. The intercalated and striated ducts were similar to those of the parotid gland except that the striated ducts in the submandibular gland were larger in diameter, more in number and concentrated in the central area of each lobe (Table 2). 


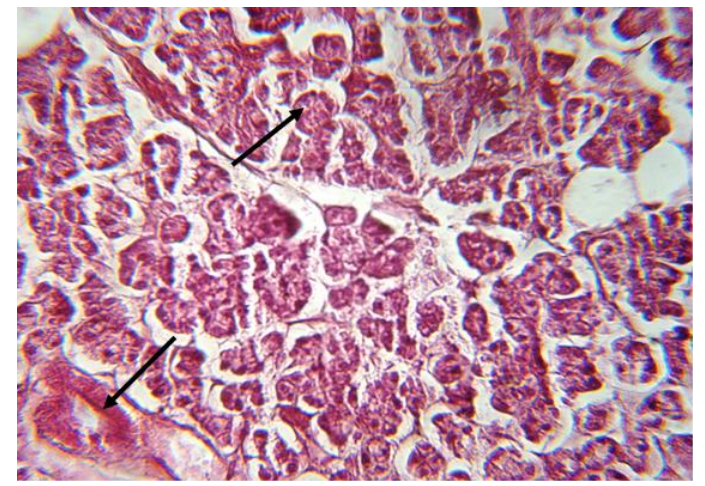

Figure (4): Light micrograph of control submandibular section, showing seromucous acini(sm) and intercalated duct (i),striated duct ( st ).H\&E. [ X- 370 ].

Table (2): Mean and standard deviation of the measurement of seromucous acini and intralobular ducts in submandibular glands

\begin{tabular}{|c|c|c|c|c|c|}
\hline \multirow[b]{2}{*}{ Parameters } & \multicolumn{2}{|c|}{ Control } & \multicolumn{2}{|c|}{ Treated } & \multirow{2}{*}{ P - value } \\
\hline & Mean $(\mu \mathrm{m})$ & SD & Mean $(\mu \mathrm{m})$ & SD & \\
\hline Diameter of acini & 21.90 & 4.03 & 18.85 & 4.03 & 0.002 \\
\hline Height of acinar cell & 11.32 & 2.18 & 8.37 & 2.34 & 0.000 \\
\hline $\begin{array}{l}\text { Diameter of intercalated } \\
\text { ducts }\end{array}$ & 20.78 & 4.39 & 15.24 & 2.20 & 0.000 \\
\hline $\begin{array}{l}\text { Height of intercalated } \\
\text { duct cells }\end{array}$ & 8.64 & 1.72 & 7.20 & 1.65 & 0.005 \\
\hline Diameter of striated ducts & 50.07 & 6.82 & 27.87 & 4.93 & 0.000 \\
\hline $\begin{array}{l}\text { Height of the striated duct } \\
\text { cells }\end{array}$ & 21.27 & 5.95 & 10.24 & 1.82 & 0.000 \\
\hline
\end{tabular}

Figures (5,6): treated parotid gland,and Figures $\quad(7,8)$ treated submandibular gland, showed loss of architecture of both glands with disarrangement of serous acini and seromucous acini, irregular shape of acinar cells marked shrinkage and smaller in diameter lead to an increase in the interstitial spaces. Striated ducts cells showed marked atrophy and shrinkage which lead to changes of the cells, from columnar to cuboidal cells, and there is a large space around all the striated duct.Intercalated duct cells showed marked atrophy and shrinkage.

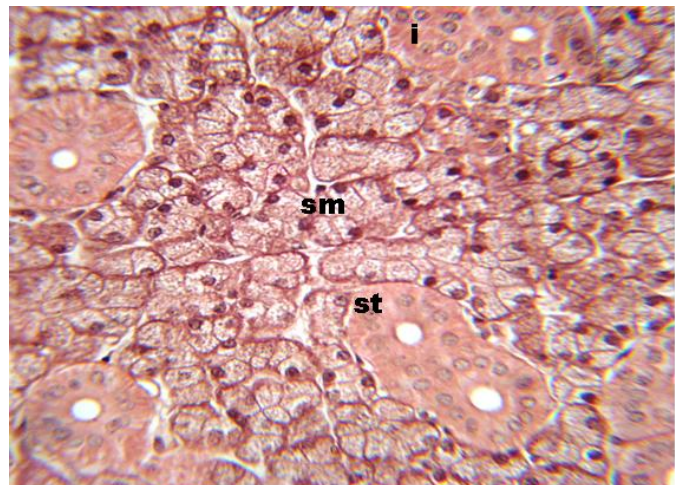

Figure (5): light micrograph of treated parotid section, showing atrophy of acinar cell and atrophy of the cell of striated duct (arrow) .H\&E. [ X-165 ]. 


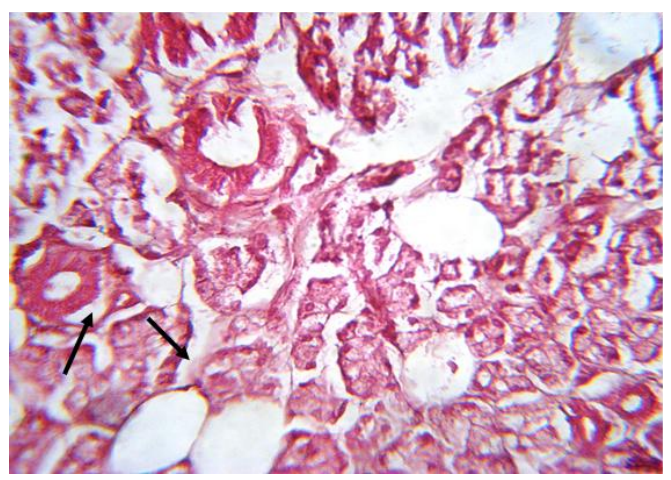

Figure (6): light micrograph of treated parotid section, showing the presence of large space around the acinar cell and the cell of the duct (arrow) .H\&E. [ X-370 ].

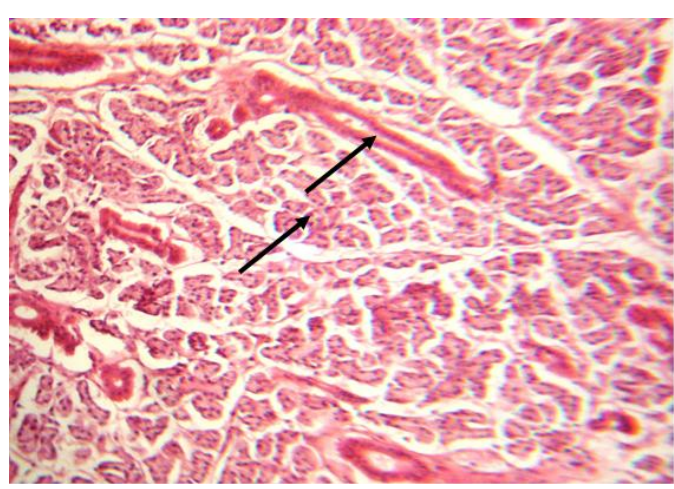

Figure (7): light micrograph of treated submandibular section, showing atrophy of acinar cell and atrophy of the cell of striated duct (arrow) .H\&E. [ X-165 ].

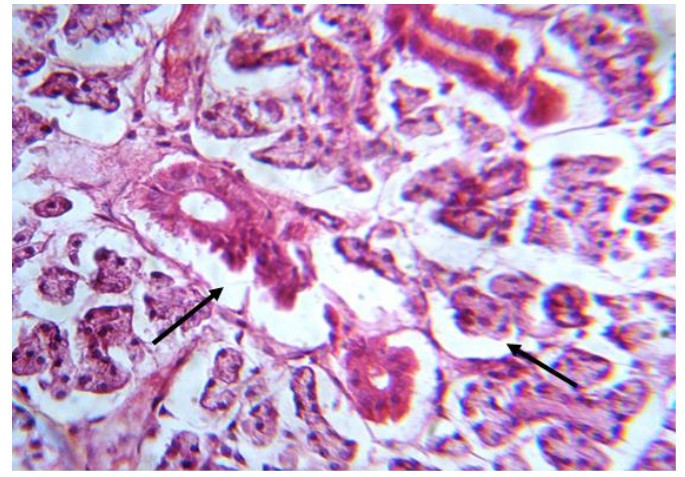

Figure (8): light micrograph of treated submandibular section, showing the presence of large space around the acinar cell and the cell of the duct (arrow) .H\&E. [ X-370 ].

Table (3) all animals showed a gradual and regular decrease in body weight over the two weeks after administration of 6 mercaptopurine (6MP).

Table (3): Body weight of rabbits before and after treatment

\begin{tabular}{lcc}
\hline & before treatment & after treatment \\
\cline { 2 - 3 } Body weight $(\mathbf{K g})$ & 1.350 & 1.340 \\
& 1.340 & 1.200 \\
& 1.250 & 950 \\
& 1.350 & 1.320 \\
\hline
\end{tabular}

* significant at $p \leq 0.005$ 
Table (1) The effect of (6MP) on parotid gland produce histological changes and a significant decrease in the diameter and height of acini and striated duct as compared to control gland, diameter of intercalated duct were slightly decreased. There were no significant differences in height of intercalated duct cells as compare to control gland Table (2) The effect of (6MP) on submandibular gland produce histological changes and a significant decrease in diameter and height of acini and intercalated and striated duct as compared to control gland

\section{DISCUSSION}

Salivary glands have become a useful investigative tool for the study of some basic problems in pharmacology ${ }^{(16)}$. Despite the low mitotic rate, salivary gland tissue loses its function regularly after exposure to chemotherapeutic doses and can cause significant reduction of saliva production causing dry mouth (xerostomia). ${ }^{(17)}$ One of the anticancer drugs is 6 -mercaptopurine that have been the backbone of maintenance chemotherapy for acute lymphoblastic leukemia of childhood ${ }^{(18)}$, it was first given to rabbits by Schwartz and Dameshek in $1960^{(19)}$. As the effects of 6MP are obviously not cell specific, it would be reasonable to expect some effects on different tissues of these animals. In this study 6MP was given to rabbits in order to study its effect on salivary glands, and it was noted that the gross weight of all animals gradually decreased with time, visible deleterious side effects like alopecia, dermatitis, gastrointestinal tumors were not observed ${ }^{(9,20)}$. The morphologically demonstrated reduction of serous tubules and ductal cells, accorded well with the histologically clear signs of chemotherapeutic damage 2 weeks after treatment and pronounced degeneration. Histologically, there was loss of architecture of both parotid and submandibular salivary glands with disarrangement of acini that showed interacinar oedema and signs of degeneration and shrinkage at 2 weeks of treatment by 6MP. Striated ducts cells showed marked atrophy and shrinkage and the acinar lumens become visible, the extent of the atrophy depends on the size of the affected duct ${ }^{(21)}$. These results was in agreement with other studies which demonstrated that cancer chemotherapy can induce salivary gland acinar degeneration in $50 \%$ of the patients studies $^{(22)}$. There were significant differences between control and treatment groups of rabbits in relation to all these changes except that for the differences in height of intercalated duct cell of parotid glands which showed no significant differences compared to control group, Therefore the subchronic administration of $6 \mathrm{MP}$ induces structural and functional changes in the rabbit salivary glands. There changes may indicate an active involvement of these glands in the 6MP intoxication since that cancer chemotherapy can cause indirect toxicities and has the potential of affecting any cell in the body that is sensitive to certain agent and can affect the oral cavity. These marked changes in the salivary glands suggest suppression and/or disruption of protein synthesis, and synthesis of abnormal proteins, this can lead to formation of cytolysosome, some may be an evidence of the distinctive process called shrinkage necrosis. This process has been described as apoptosis in a number of tissues and the apoptotic bodied which are found in small numbers in normal tissues are greatly increased in tissues which have been subjected to chemotherapy. So ,in this study the salivary gland cells affected by $6 \mathrm{MP}$ were underwent either cell death or injury which causes damage ${ }^{(5,9,23)}$. Other possible mechanism of these changes in salivary glands was injury of the gland cells and to epithelium of salivary gland ducts which is associated with inflammation and fibrosis with raised possibility of autoimmune response ${ }^{(17,24)}$. All these changes that can reduce salivary flow rate and induce changes in composition of saliva will contributing to compromising the mucosal barrier function and increase risk of oral infections. ${ }^{(25)}$ 


\section{CONCLUSIONS}

Oral tissue damage resulting from toxicities of cancer chemotherapy can have significant impact on the course of cancer therapy, salivary glands that have the main function of secreting saliva can be considerably affected leading to dysfunction of salivary glands which can cause important problems for patients and for clinicians trying to manage them.

\section{REFERENCES}

1. Pickelt FA, Terezhalmy GT. Cancer chemotherapy. In: Basic principles of pharmacology with dental hygiene applications. Lippincott Williams and Wilkins. 2009. P. 282.

2. Pieters R. Acute lymphoblastic leukemia. Ned Tijdschr Geneeskd. 2010; 154 (35): A 1577.

3. Fakhoury M, de Beaumais T, Medard Y, Jacqz - Aigrain E. Theraputic drug monitoring of $6-$ thioguanine nucleotides in peadiatric acute lymphoblastic leukemia: interest and limits. Therapie. 2010; 65(3): 187 193.

4. Laurence L, Keith L. Purine analogs. In: Goodman and Gilman's manual of pharmacology and therapeutics. McGraw Hill. 2008. P. 878.

5. Yagiela A, Dowd F, Neidle E. Antineoplastic drugs. In: Pharmacology and therapeutics for dentistry. Elsevier Mosby. $5^{\text {th }}$ ed. 2004. Pp. $697-799$.

6. Lgenl T, Ören H, Uysal K. The acute effects of chemotherapy upon the oral cavity: prevention and management. Turkish J Cancer. 2001; 31(3): 1093 $-2001$.

7. Pols TW, Bonta PI, Pires NM, et al . 6 - mercaptopurine inhibits a therosclerosis in a polipoprotein $\mathrm{e}^{*} 3$ leiden transgenic mice through a theroprotective actions on monocytes and macrophages. Arterioscler Thromb Vasc Biol. 2010; 30(8): 1591 $-1597$.

8. Keys DW, Adkins KF. Effects of prolonged administration of azathioprine on parotid glands of rats: as assessment by light microscopy. Aust Dent J. 1981; 26(6): 372 - 376.
9. Keys DW, Adkins KF. Effects of prolonged administration of azathioprine on parotid glands of rats: as assessment by electron microscopy. Aust Dent J. 1982; 27(2): $98-108$.

10. William J, George N. The effects of 6- mercaptopurine (6MP) on the thyroid gland. Endocrinology. 1974; 94(6): 1583 - 1586.

11. Nachtigal D, Feldman M. Immunological unresponsiveness to protein Antigens in rabbits exposed to $\mathrm{X}$ - irradiation or 6 - mercaptopurine treatment. Immunology. 1963; 6(4): $356-369$.

12. Bredikhin L, Storozhenko M, Davxdov M, Nikulin M. Experimental thyroid hemografting during inhibition of the recipient's defensive reaction by immunodepressents. BUllETIN of EXPERIMENTAL BIOLOGY AND MEDICINE. 1973; 75(5): 58 - 60.

13. Jason W, Rachel E. Body surface area nomogram and equation. In the HARRIET LANE HANDBOOK. Mosby Elsevier, $18^{\text {th }}$ ed. 2009. P. 1032.

14. Al-Safi S, Tashtoush B, AbdulRazzak IK. Azathioprine - induced fatal macrocytic anemia in rabbits. Pol J Pharmacol. 2002; 54(5): 513 516.

15. Humanson G. Animal tissue technique. San Francisco W.H. Freeman and Company. $3^{\text {rd }}$ ed. 1972. P. 125-136.

16. Rafah A, Alhan DH, Tahani A. Effect of natural apple cider vinegar on morphometric changes of salivary glands in hydroxyl urea treated mice. J Edu Sci. 2006; 18(3): 62 - 77.

17. Bo H, Evy H, Magnus G. Influence on rabbit submandibular gland injury by stimulation or inhibition of gland function during irradiation. Annals of Otology Rhinology and Laryngology. 1994; 103(2): 125 - 134.

18. Max L, Wang B, et al. Tolerability of 6 - mercaptopurine in children with acute lymphoblastic leukemia. Zhonghue Er Ke Za Zhi. 2010; 48(4): $289-292$. 
19. Scwartz R, Dameshek W, Donovan J. Development of drugs to control rejection. J Clin Invest. 1960; 39: 952.

20. Finkel R, Clark A, Cubeddu L. Anticancer drugs. In: Lippincott's illustrated review: Pharmacology. Lippincott Williams and Wilkins. 2009. P. 465.

21. Lucie A. Comparative histoenzymology of the salivary glands. Ann N.Y. Aead Sci. 1963; 106: $472-492$.

22. Lockhart PB, Sonis S. Alterations in the oral mucosa caused by chemotherapeutic agents. J Dermatol Surg Oncol. 1981; 7: 1019 - 1025.

23. Chlarenza A, Elverdin E, Giglio M. Effects of Cadmium on the function and structure of the rat salivary glands. Archs Oral Biol. 1989; 34(12): $999-1002$.

24. Ahlner H Hagalqvist E, Magnus G, Bengt - Inge R. Irradiation of rabbit submandibular glands. Acta Otolary. 1993; 113: $1-10$.

25. Squier C. Mucosal alterations. NCL Monogr. 1990; 9: 169 - 172. 